\title{
Leading Factors to Surrogacy From Pregnant Surrogate Mothers' Vantage Point: A Qualitative Research
}

\author{
Mina Shayestefar ${ }^{1}$, Heidarali Abedi ${ }^{*}$
}

\begin{abstract}
Objectives: Infertility is the absence of pregnancy after 1 year of intercourse without contraceptive methods. This research aimed at exploring primary factors leading to surrogacy.

Materials and Methods: The present qualitative study was based on phenomenology approach. Participants were pregnant surrogate mothers referring to Isfahan Fertility and Infertility Center in 2014. Sampling was conducted using purposeful method through which 5 women were selected. Data collection was done utilizing deep and unstructured interviews which were then analyzed based on Colaizzi method. Reliability and validity of this study consisted of 4 elements including dependability, credibility, transfer-ability and confirm ability.

Results: The mean age \pm standard error (SE) of participants was $32.4 \pm 0.4$ years. Overall, after analyzing the interviews, 74 primary codes associated with leading factors of surrogacy were extracted. The primary codes were categorized into 7 subthemes, namely, life background, failures and ineffective efforts to improve life, economical impasse, seeking independence, altruism, compulsion, sin atonement and making a trade with God. Finally, these 7 subthemes were integrated and the theme of "primary factors leading to surrogacy" was made.

Conclusion: Care and support systems should be invigorated in Iran so that derelict women could have insurance and are not compelled to donate ovum or undertake surrogacy several times. Exploitation of these women should be prevented and harm to human dignity must not happen.

Keywords: Infertility, Surrogate mothers, Qualitative research
\end{abstract}

\section{Introduction}

Infertility is the absence of pregnancy after 1 year of intercourse without contraceptive methods (1). Infertility is highest in some regions including South Asia, subSaharan Africa, North Africa, Middle East, Central/ Eastern Europe and Central Asia (2). Prevalence of infertility during life and primary infertility were $21.1 \%$ and $6.4 \%$, respectively in four provinces of Iran namely Golestan, Qazvin, Kermanshah and Hormozgan from 2010-2014 (3). Infertility can widely affect couple's quality of life, psychological, physical, social and individual dimensions of their lives (4-6).

Surrogacy is an assisted reproductive technology (ART) method through which a surrogate mother accepts pregnancy in order to bear another woman's child in her womb. The term 'surrogate' has been loaned from the Latin word 'subrogar' which means 'alternative' (7). It helps patients with history of repeated implantation failure (RIF) (8).

There are few statistics about surrogacy, although it seems it is increasing. However, Centers for Disease Control and Prevention (CDC) and the Society for Assisted Reproductive Technology (SART) have reported that the number of babies born by gestational surrogacy almost doubled from 2004 to 2008 and it is surely rising (9).

Despite the advantages of surrogacy, it has given a cause to some legal and moral issues (10). Jadva and Imrie state that there are a few studies about experience of surrogate mothers and upgrading their psychological health (11). On the other hand, qualitative research is suitable for scopes where there is not enough information on this issue or to explore the implications of data from different feelings, behavior, beliefs and measures $(12,13)$.

In naturalistic research, each participant has his or her viewpoint to world and meaning of phenomenon can be created by shared idea (14).

Qualitative research is a method to gain insights through exploration of meanings. The insight is not gained through detecting the relation between causes and effects, rather through improving understanding the total incident. Therefore, in qualitative research, sampling focuses on the experiences and events which are able to provide extensive information on the experience or event under investigation (15). Purpose of sampling is sharing knowledge (16).

From the time women decide to rent a womb to the postpartum, they face various issues which affect their quality of life and lots of these issues are unknown for 
medical teams. Despite the studies conducted on this area, there is not enough knowledge available in surrogacy. The aim of this research was to explore the leading factors to surrogacy obtained from pregnant surrogate mothers experiences referring to Isfahan Fertility and Infertility Center in 2014.

\section{Materials and Methods}

Study Design

This qualitative research was based on phenomenology approach. This study was based on the philosophy of naturalistic research. In a holistic framework, qualitative research is considered as a tool for deep, rich and inherently complex exploration of a phenomenon. The insight gained from this process will guide the nursing practice and will help the important procedure of theory development in generating nursing knowledge.

Setting and Sample

Sampling started from 21 April 2013 and continued until 22 October 2013. Participants were 5 pregnant surrogate mothers referring to Isfahan Fertility and Infertility Center who were willing to cooperate. Participants were selected based on purposive method and their knowledge of surrogacy phenomenon. Sampling was continued until data saturation. During sampling, researchers faced with some restrictions including unwillingness of many women to be interviewed, having no place for interviewing, frequent impossibility of inviting the pregnant women to other places except the Center to be interviewed.

\section{Instrument}

Deep and unstructured interviews were applied to obtain research data. The interviews took variedly between 30 and 45 minutes. The first minutes would be about everyday conversation. After creation of a favorable and friendly environment, interviews would begin with an extensive and central question about the participants' life experiences. If there were any ambiguous, short and incomplete answers, further questions would be asked to clarify participants' statements.

\section{Data Collection}

Each interview was tape recorded with the permission of the participants, and would be transcribed and scrutinized at leisure time. All of the interviews are available for supervisors reload.

\section{Data Analysis}

Data were analyzed based on Colaizzi 7-stage method because this method of data analysis is associated with descriptive phenomenology (17). According to Holloway (18), for making empathy with participants, each interview was read several times and then phrases directly associated with surrogacy phenomenon were extracted and underlined. In the first stage of Colaizzi method, the researchers tried to achieve empathy through several readings of interviews. In the next stage, second stage of Colaizzi method, phrases (primary codes) directly associating with surrogacy phenomena were extracted and underlined.

These primary codes were categorized to 7 subthemes. In order to implement the third stage of Colaizzi method, the researchers tried to conceptualize and formulate extracted meanings from the sentences underlined. Finally, after the interviews, data extraction, and coding, for making credibility in data, the researchers referred to each participant again to assess their agreement with the researchers.

Data credibility was verified via using member checking and peer debriefing by Isfahan Fertility and Infertility Center consulting group to promote trustworthiness of the study. Guba and Lincoln applied the following terms to gain accuracy and power in qualitative research which included credibility, dependability, transferability and confirmability (19).

Validity includes all the activities which increase the probability of obtaining valid data. The best way of dependability proof and verification is to deal with the subject under study in the long term. Reliability results after researchers prove validity of data. Similar to validity of quantitative research, validity without reliability is not possible. This matter is similar to reliability in qualitative studies, where reliability is not attained without validity. Confirmability is a gradual and continuous criterion. To obtain confirmable data, the researcher has to record the entire interview. Transferability means the possibility of making similar sense by the research results for others in a similar situation. In addition to the transferability, a detailed report of the study provided that emphasizes proper sampling.

\section{Results}

Overall, after analyzing the interviews, 74 primary codes associated to leading factors of surrogacy were extracted. In the fourth stage, the researchers categorized the primary codes which were categorized into 7 subthemes: life background, failures and ineffective efforts to improve life, economical impasse, seeking independence, altruism, compulsion, sin atonement and making trade with God. Altruism subtheme consists of 4 codes: preservation of life on the brink of divorce, making happy the receptor families, empathizing with the receptor family and beneficence. Finally, in the fifth stage, these 7 subthemes were integrated and a theme of "leading factors to surrogacy" was made which is demonstrated in Figure 1. This diagram formed the sixth stage of Colaizzi method which is named as an inherent structure of the phenomenon.

In order to achievement the last stage of Colaizzi method, the researchers referred to all participants.

Below examples of participants' statements related to 7 extracted subthemes were explained:

\section{Life Background}

The participants' age ranged from 31 to 33 years. The mean age \pm standard error (SE) of participants was $32.4 \pm$ 


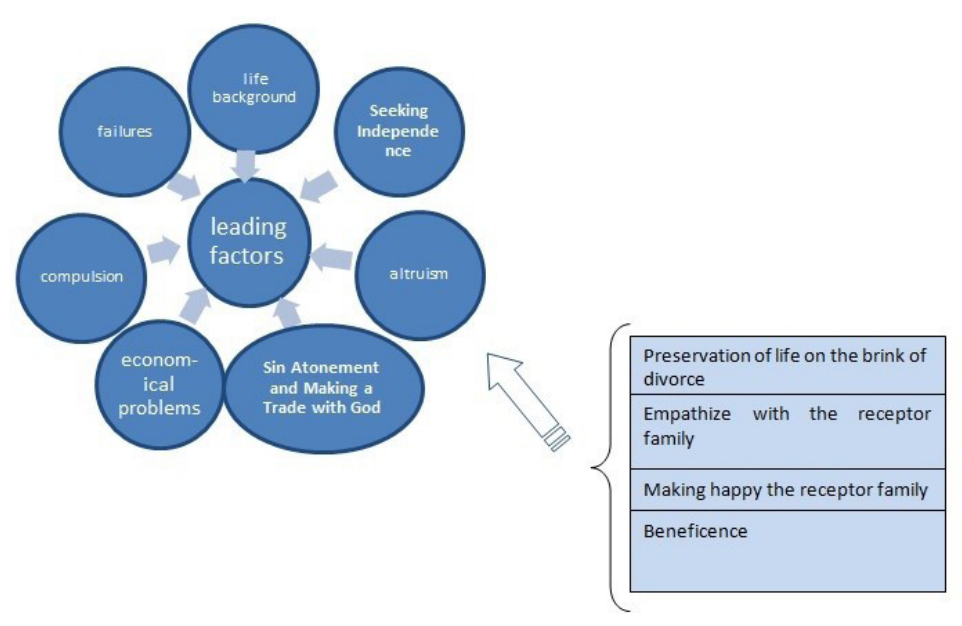

Figure 1. Circumstance of Secondary Codes and Main Theme Formation.

0.4 years $(P<0.05)$. Two participants were divorced and others married. Educational level of them varied from being illiterate to having diploma. All of the participants had 1-2 children aging 6-12 years. All participants' spouses were self-employment. Most of the participants were housekeepers except one of them. Nevertheless, some participants had experienced occupations including sales, elderly nursing, home care nursing and hairdressing (Table 1). For example:

“... I have married for about 10 years. It was not a good marriage at all. We used to suffer from bad luck. Then we decided to divorce. After divorce, I decided to have surrogacy last year. I delivered a twin girl. I couldn't make ends meet. I lived alone. Still I live alone in...Also, I donated an oocyte 2 months ago, which was again because of money. Now I came for surrogacy again ... and they transferred a fetus to my womb...." Participant number 4 :

Failures and Ineffective Efforts to Improve Life

“... Honestly, we had a difficult life, although my husband worked hard, but we could not manage our expenses with having a child..." (Participant number 5).

"... I had too a hard life, I took a 10 million Tomans loan for business in cosmetics shop. But I could not manage the store and I became bankrupt...I wanna live for myself. I tried a lot. I opened a shop, but I was

Table 1. Demographic Parameter of Surrogate Mothers

\begin{tabular}{lc}
\hline Parameter & No. of Cases (Mean \pm SE) \\
\hline Age $(y)$ & $32.4 \pm 0.4$ \\
Marital status & 3 \\
Married & 0 \\
Widow & 2 \\
Divorced & \\
Educational level & \\
Illiterate & 3 \\
Diploma & 2 \\
Academic & 0 \\
\hline
\end{tabular}

not successful. After that I tried for elderly nursing, its salary was good but it was a really demanding job; I had to stay awake round the clock..." (Participant number 2).

\section{Economical Impasse}

“... When I got married, my husband was a soldier. We had lots of problems but our family could not help us... First I came here only because of money... now I come here to add it to the previous amount to buy a house..." (Participant number 1).

“...If I did not need money I would not become surrogate. I took a loan and worked with it, but I failed and could not run the store. Now I owe 5 million Tomans. I came here to pay off the loan. Then I will rent a house ..." (Participant number 2).

“...After getting divorced, I decided to surrogacy last year. I delivered a twin girl. I couldn't make ends meet. I live alone in.... Also I donated an oocyte 2 months ago because of money. Now I'm here for surrogacy again ..." (Participant number 4).

“...The house rent is high and it was so difficult. We couln't go on anymore. Finally a person introduced this center to me to earn money through surrogacy..." (Participant number 5).

Seeking Independence

“... When I talked with my father about surrogacy, he opposed immediately. I said that I do not like to take money from you... People say she is divorced and now has come back to her father's home with 2 children. Everyone thinks of me as an extra member but I want to live for myself..." (Participant number 2).

"Lots of families do not accept surrogacy. My parents opposed this idea too. They said you will destroy your body. I said who would help me? I have nobody for financing, I had to do this. I am a derelict woman; I have no one to help me. When women have no one to help them, they have to do things like this to earn some money..." (Participant number 4). 
Altruism

“... I want to earn honest (Halal) money and avoid misdeed. Now I am a surrogate mother and just hope and want for those infertile women to experience maternal sense and may God not frustrate them ..." (Participant number 2).

"... I can say that surrogacy is a good experience. I can make a family happy. In fact, when I came for fetus donation and saw different couples who are divorcing because of infertility then I stopped thinking about payment ..." (Participant number 3 ).

“... After all, I can pay some of the debts. Besides, a family will experience having a child and won't get divorce. Some couples are so young..." (Participant number 5).

"... I feel good, because that family has been infertile for 20 years. For one thing that family would become happy and I also told myself God will compensate for this good deed of mine..." (Participant number 4).

"... That woman had a fake Cesarean Section, because she did not like her relatives to gossip about her so she came here to make sure that no one knows about her infertility. They have lots of problems, too and I do not like to upset her and say I gave birth to the children ..." (Participant number 4).

Compulsion

“... My husband insisted for surrogacy and ovum donation and he followed up for its arrangements. Honestly, we had financial problems and my husband wanted me to do it..." (Participant number 3).

"...First my husband was hesitant but there has been and still are so many problems that I finally decided to bother me to earn some money to solve some of our problems..." (Participant number 5).

"...As a derelict woman, who would help me? Women without any supporters have to do things like this to earn money..." (Participant number 4).

\section{Sin Atonement and Making a Trade With God}

"...I found pills by help of a stranger man and aborted my fetus. After 2 months, I got depressed. Always I remember the sense of abortion (she cried). I tried to compensate that sin to decrease suffering my conscience. Now I want to receive the money based on the center agreement so decrease suffering my conscience. I act as a surrogate mother to compensate for my child and have oblation (Savab). Then I won't say: 'I killed somebody'...' (Participant number 2).

"... She and her husband were crying. After that the money was not important and I thought that I could make a family happy. God will grant some blessing for me in some other ways..." (Participant number 1).

\section{Discussion}

Surrogacy is considered as an emotional experience (20) so this research aims at exploring the leading factors to surrogacy. As it could be discerned from results, leading factors of surrogacy included life background, failures and ineffective efforts to improve life, economical impasse, independence seeking, altruism, compulsion, sin atonement and making a trade with God.

\section{Life Background}

Age ranges of participants were 31-33 years. With the age mean of 32.4 years. It has to be notified that young families with low income experience higher levels of stress and often experience injuries in their earlier lives. They face higher risks of depression, family conflict, divorce, etc (21).

Most of the participants had history of fetus or oocyte donation. Also another study revealed that these intentions were the most important aspects of future desire for surrogacy in women (22). 2 participants were divorced and others (3 participants) were married. In Islamic Republic of Iran with Shia religion, one of the surrogacy conditions is having marriage experience (having lost their virginity due to legitimate marriage) and only widow and divorced women can donate oocyte. The experiences of surrogate mother from ethical issues were assessed by Aramesh. Sunni jurists have rejected surrogacy while Shia jurists have acquiesced in it only under legitimate marriages and certain conditions (23).

Failures and Ineffective Efforts to Improve Life Failures and ineffective efforts to improve life is one of the leading factors of surrogacy. Pizitz et al (21) in a study which aimed at comparing mental status of surrogacy women revealed that surrogate mothers had mixture of sensitive and rigid thoughts, and lower scores in MMPI-2 test, compared with normal women.

\section{Economical Impasse}

One of the extracted subthemes was economical impasse imposed on these women. Aramesh (23) has also suggested that the main concern of surrogate mothers is economic relationship between recipient (biologic mother) and donor (surrogate mother) family and this relationship should be improved and contracted in normal ranges costs.

Cundiff et al (24) described socioeconomic status as education level and income.

Economical impasse and some other subthemes are of important factors which lead to surrogacy. All of the participants with economical problems intended to earn money through surrogacy but over time their attitudes altered.

\section{Seeking Independence}

As mentioned previously, the inceptive which may drive these women to consent to surrogacy is to seek independence from their parents, their previous husbands, etc. According to Asghari (25), a point rising in individual autonomy is the issue of electoral right of a woman to be a substitute mother. She has to decide whether other family members' rights are involved in doing so. In fact, 
here, mother's autonomy is in contrast with other family member's non-maleficence. Certainly choice freedom in this matter should lead to harm to family members and foundations. Also, husband's participation in decisionmaking to protect family relationships and helping the substitute mother in taking this responsibility is important and effective.

Ahmad (26) suggested that some feminists' attitude opposes surrogacy due to certain political and economic issues. They cannot accept freely choosing of surrogacy by women although some of them believe that ART is a positive priority since it brings more control and gift motherhood to another woman.

\section{Altruism}

All surrogate mothers have feeling of altruism, they were glad of being helpful for infertile women and can save a life. There is lack of documented definition for altruism, for a long time altruism is used as a guide for accepting or rejecting certain types of donation in the United Kingdom (27).

Altruism subtheme consists of 4 codes: preservation of life on the brink of divorce, making happy the receptor families, empathizing with the receptor family, and beneficence. Kerr et al (28) stated that altruism is generally defined as an individual behavior that a person benefits others by personal expense.

Asghari (25) states that "the discourse of justice in surrogate mothers is avoidance of exploitation of lowincome and poor women in favor of giving service and benefit to the high earners." The surrogate brokers can intensify this exploitation. Therefore, only altruism surrogacy should be promoted and payment to surrogate mother should be so much to compensate time, expenses and efforts. It should not be seductive for tempting to this responsibility.

Uzefovsky et al (29) have defined that empathy is ability of perceiving and sharing others emotion. It has two aspects including cognitive and emotional and it is a multidimensional meaning.

Pashmi et al (30) concluded that in process of surrogacy there are lots of issues including social, legal and psychological; and understood in this process women are satisfied and experience altruistic emotion, overall donor and recipient mothers are satisfied.

Accordingly, one of the extracted subthemes after the interview analysis was altruism which was formed from 4 codes: preservation of life on the brink of divorce, making happy the receptor families empathize with the receptor family, beneficence.

Sin atonement and making a trade with God

Some of surrogate mothers had bad experience like induced abortion and tried to atonement their sin. In fact they made a trade with God. Nakagawa et al (31) noted that lots of individual and social cognitions make guilty feeling including punishment, empathy and moral reasoning.

\section{Limitations}

As mentioned, during sampling, researchers faced with some restrictions including unwillingness of many women to be interviewed, having no place for interviewing, and impossibility of inviting the pregnant women to other places except the Center to be interviewed.

\section{Conclusion}

There are few statistics about surrogacy although it seems its usage is increasing rapidly. Nowadays, there is not enough knowledge on surrogacy; therefore, more exploration necessity in life of surrogate mothers and country planning to issue guidelines is felt.

Surrogacy is associated with lots of psychological issues, which entails consultation for surrogate mothers and education is the best way of prevention from exploitation. We should consider that, improving women's health improves family health and finally society's health. It is recommended that to give complete care and special consultation for recipient and donor family before, during and after pregnancy.

Care and support systems should be invigorated in Iran so that derelict women have insurance and are not compelled to donate ovum and have surrogacy several times. Exploitation of these women should be prevented and harm to human dignity in them must not occur, because it will impose physical and psychological stress on them. As mentioned, education is the best way of exploitation prevention.

Motherhood love and affection increases during pregnancy and progress. Surrogacy cannot affect the motherhood feeling. In this regard, there are some concerns that can be removed through careful ratification, surrogacy contract and two sides' awareness.

\section{Ethical Issues}

Researchers received the ethics code from Regional Committee for Medical Research Ethics of Isfahan Medical University reference to Isfahan Fertility and Infertility Center. Before starting interviews, all of the participants signed the informed consent form and interviewer explained it briefly. This article is actually based on a part of Nursing Mastery thesis approved in Islamic Azad University of Isfahan, Khorasgan Branch and Regional Committee for Medical Research Ethics of Isfahan Medical University (ethical code ID: 493020).

\section{Conflict of Interest}

There is not any conflict of interest.

\section{Financial Support}

None to be declared.

\section{Acknowledgments}

The authors feel obliged to express their gratitude about cooperation of Isfahan Fertility and Infertility Center, participants and authorities of Research Council in Nursing Department of Isfahan (Khorasgan) Branch, 
Islamic Azad University and Regional Committee for Medical Research Ethics of Isfahan Medical University.

\section{References}

1. Berek JS, Novak E. Berek and Novak's Gynecology. 14th ed. Philadelphia: Lippincott Williams and Wilkins; 2011.

2. Mascarenhas MN, Flaxman SR, Boerma T, Vanderpoel $\mathrm{S}$, Stevens GA. National, regional, and global trends in infertility: a systematic analysis of 277 health surveys. PLoS Med. 2012;9(12):e1001356. doi:10.1371/journal. pmed.1001356.

3. Rostami Dovom M, Ramezani Tehrani F, Abedini M, Amirshekari G, Hashemi S, Noroozzadeh M. A populationbased study on infertility and its influencing factors in four selected provinces in Iran (2008-2010). Iran J Reprod Med. 2014;12(8):561-566.

4. Baldur-Felskov B, Kjaer SK, Albieri V, Steding-Jessen M, Kjaer T, Johansen C, et al. Psychiatric disorders in women with fertility problems: results from a large Danish registerbased cohort study. Hum Reprod. 2013;28(3):683-690. doi: 10.1093/humrep/des422.

5. Kjaer TK, Jensen A, Dalton SO, Johansen C, Schmiedel S, Kjaer SK. Suicide in Danish women evaluated for fertility problems. Hum Reprod. 2011;26(9):2401-2407. doi: 10.1093/humrep/der188.

6. Penrose R, Beatty L, Mattiske J, Koczwara B. The psychosocial impact of cancer-related infertility on women: a review and comparison. Clin J Oncol Nurs. 2013;17(2):188-193. doi:10.1188/13.CJON.188-193.

7. Anu, Kumar P, Inder D, Sharma N. Surrogacy and women's right to health in India: issues and perspective. Indian J Public Health. 2013;57(2):65-70. doi:10.4103/0019557X.114984.

8. Aflatoonian N, Eftekhar M, Aflatoonian B, Rahmani E, Aflatoonian A. Surrogacy as a good option for treatment of repeated implantation failure: a case series. Iran J Reprod Med. 2013;11(1):77-80.

9. GuguchevaM.Surrogacyin America.Councilfor Responsible Genetics. http://www.councilforresponsiblegenetics.org/ pagedocuments/kaevej0a1m.pdf.

10. Rahmani A, Sattarzadeh N, Gholizadeh L, Sheikhalipour Z, Allahbakhshian A, Hassankhani H. Gestational surrogacy: viewpoint of Iranian infertile women. J Hum Reprod Sci. 2011;4(3):138-142. doi:10.4103/0974-1208.92288.

11. Jadva V, Imrie S. Children of surrogate mothers: psychological well-being, family relationships and experiences of surrogacy. Hum Reprod. 2014;29(1):90-96. doi: 10.1093/humrep/det410.

12. Abedi HA. Applying phenomenological method of research in clinical sciences (Persian). Rahbord. 2010;54:207-224.

13. Boroumandfar K, Saghafi Z, Abedi HA, Bahadoran P. Consequences of unwanted pregnancy (Persian). Iran J Nurs Midwifery Res. 2005;10(4):25.

14. Lincoln YS, Lynham SA, Guba EG. Paradigmatic controversies, contradictions, and emerging confluences, revisited. In: Denzin NK, Lincoln YS, eds. The SAGE Handbook of Qualitative Research. Thousand Oaks, CA:
Sage; 2011:97-128.

15. Burns N, Grove SK. The Practice of Nursing Research: Appraisal, Synthesis, and Generation of Evidence. 6th ed. USA: Saunders; 2009.

16. Streubert H, Carpenter DR. Qualitative Research in Nursing: Advancing the Humanistic Imperative. 5th ed. Philadelphia: Lippincott Williams \& Wilkins; 2010.

17. Cohen MZ, Kahn DL, Steeves RH. Hermeneutic Phenomenological Research. Thousand Oaks, CA: Sage; 2000.

18. Holloway I. A-Z of Qualitative Research in Health Care. 2nd ed. Australia: Black well Publishing; 2008.

19. Guba EG, Lincoln YS. Competing paradigms in qualitative research. In: Denzin NK, Lincoln YS. Handbook of Qualitative Research. Thousand Oaks, CA: Sage; 1994.

20. Ahmari Tehran H, Tashi SH, Mehran N, Eskandari N, Dadkhah Tehrani T. Emotional experiences in surrogate mothers: a qualitative study. Iran J Reprod Med. 2014;12(7):471-480.

21. Pizitz DT, McCullaugh J, Rabin A. Do women who choose to become surrogate mothers have different psychological profiles compared to a normative female sample? Women Birth. 2013; 26(1):e15-e20.

22. Poote AE, van den Akker OBA. British women's attitudes to surrogacy. Hum Reprod. 2009;24(1):139-45. doi: 10.1093/ humrep/den338.

23. Aramesh K. Iran's experience with surrogate motherhood: an Islamic view and ethical concerns. J Med Ethics 2009;35(5):320-322. doi: 10.1136/jme.2008.027763.

24. Cundiff JM, Uchino BN, Smith TW, Birmingham W. Socioeconomic status and health: education and income are independent and joint predictors of ambulatory blood pressure. J Behav Med. 2013;38(1):9-16. doi:10.1007/ s10865-013-9515-8.

25. Asghari F. Ethical issues in surrogate motherhood (Persian). J Reprod Infertil. 2008;9(1):30-5.

26. Ahmad N. An international view of surgically assisted conception and surrogacy tourism. Med Leg J. 2011;79(4):135-145. doi: 10.1258/mlj.2011.011029.

27. Moorlock G1, Ives J, Draper H. Altruism in organ donation: an unnecessary requirement? J Med Ethics. 2014;40(2):134138. doi:10.1136/medethics-2012-100528.

28. Kerr B, Godfrey-Smith P, Feldman MW. What is altruism? Trends Ecol Evol. 2004;19(3):135-140. doi:10.1016/j. tree.2003.10.004.

29. Uzefovsky F, Shalev I, Israel S, Edelman S, Raz Y, Mankuta D, et al. Oxytocin receptor and vasopressin receptor 1a genes are respectively associated with emotional and cognitive empathy. Horm Behav. 2015;67:60-65. doi:10.1016/j. yhbeh.2014.11.007.

30. Pashmi M, Tabatabaie SMS, Ahmadi SA. Evaluating the experiences of surrogate and intended mothers in terms of surrogacy in Isfahan. Iran J Reprod Med. 2010;8(1):33-40.

31. Nakagawa S, Takeuchi H, Taki Y, Nouchi R, Sekiguchi A, Kotozaki Y, et al. Comprehensive neural networks for guilty feelings in young adults. Neuroimage. 2015;105:248-256. doi:10.1016/j.neuroimage.2014.11.004.

Copyright ( 2017 The Author (s); This is an open-access article distributed under the terms of the Creative Commons Attribution License (http://creativecommons.org/licenses/by/4.0), which permits unrestricted use, distribution, and reproduction in any medium, provided the original work is properly cited. 